\title{
The New Industrializing Factor of Russian Economy's Sustainable Development
}

\author{
Olga Aleshina ${ }^{1, *}$, Svetlana Demchenko ${ }^{1}$, Yulia Suslova ${ }^{1}$, and Andrey Voloshin ${ }^{1}$ \\ ${ }^{1}$ Siberian Federal University, 660075 Lida Prushinskaya St. 2, Krasnoyarsk, Russia
}

\begin{abstract}
The large-scale structural transformations of Russian economy - the new industrialization - is a core of its transition to sustainable development. The importance of new industrialization is proved by the possibility of overcoming technical and technological lagging behind the leading countries and expanding deep processing and high-tech industries. Based on the analysis of statistics, the features of structure of economy of Russia are revealed. It is shown that transition to new industrialization is a characteristic of the industrially developed countries of the world and the source of environment-friendly industries' boosting. The mechanism of the "window of opportunities" implementation when changing technological layers is considered. The hypothesis of a research assumes that opening the "window of opportunities" when replacing the fifth technological layer with the sixth, is a reference point for definition of the directions of strategic transformations in the context of sustainable development and extended environment protection.
\end{abstract}

\section{Introduction}

At present, no one doubts the futility of further development of the Russian economy in the framework of the raw materials exporting model. The inconsistency of this model is confirmed by a number of signs, including the distancing from sustainable development and worsening of environmental problems. The lack of ecologically oriented sources of economy's growth leads to the federal budget deficit, the decline in the incomes of the country's population and the dependence of the national currency on oil prices. These problems are not just current or short-term, but systemic and, without their practical solution, it is impossible to fulfill any of the economic and social tasks that our country is facing today's reality.

The need to form a new model of Russia's sustainable development and to search for new sources of economic growth has been vividly discussed by researchers since the $2000 \mathrm{~s}$, both in the economic and ecological studies. This was primarily due to the tendency towards pre-industrial type of economic growth, due to the country's obvious technological decline and insufficient attention to positive environmental changes.

\footnotetext{
* Corresponding author: olga24reg@mail.ru
} 


\section{Materials and Methods}

The policy of neoliberalism which is carried out within the last 15 years in Russia with a monetary bias contributed to the development of deindustrialization, degradation of the real sector of economy and many knowledge-intensive productions, especially industrial ones, strengthening of external technological dependence and strengthening the impact on environment. As a result of deindustrialization Russia has endured powerful recession practically on all positions of the industrial nomenclature. Many strategically important industries, such as machinery, agricultural engineering, and civil shipbuilding have been stagnating for many years. Position of the branches specializing in electronics, chemical fibers, complicated consumer goods is not much better. [1].

Year after year, during the market reforms, the specific weight of industrial production in national economy was steadily reduced while the share of a raw component increased, that is presented in Table 1. It resulted in the growth of environment pollution. Other tendency which is distinctly shown for this period is expressed in the rapid growth of branches of a services sector, connected with finance, insurance, consulting, promotion and IT, as a form of transition to post-industrial economy.

Table 1. The GDP of Russia (by types of economic activity, in the prices of 2008), RUB billion.

\begin{tabular}{|l|c|c|c|c|c|c|c|c|c|c|}
\hline & $\mathbf{2 0 0 7}$ & $\mathbf{2 0 0 8}$ & $\mathbf{2 0 0 9}$ & $\mathbf{2 0 1 0}$ & $\mathbf{2 0 1 1}$ & $\mathbf{2 0 1 2}$ & $\mathbf{2 0 1 3}$ & $\mathbf{2 0 1 4}$ & $\mathbf{2 0 1 5}$ & $\mathbf{2 0 1 6}$ \\
\hline GDP, including & 39219 & 41277 & 38049 & 39762 & 41458 & 42873 & 43411 & 49921 & 46551 & 45632 \\
\hline $\begin{array}{l}\text { Agricultural } \\
\text { industry }\end{array}$ & 1397 & 1487 & 1509 & 1326 & 1521 & 1466 & 1529 & 1680 & 1810 & 1791 \\
\hline Mineral extraction & 3254 & 3285 & 3207 & 3420 & 3536 & 3594 & 3457 & 3934 & 4072 & 3913 \\
\hline $\begin{array}{l}\text { Processing } \\
\text { industry }\end{array}$ & 6298 & 6164 & 5263 & 5716 & 6075 & 6248 & 6490 & 5789 & 5888 & 5521 \\
\hline $\begin{array}{l}\text { Services and other } \\
\text { branches }\end{array}$ & 22490 & 24248 & 22831 & 23677 & 24308 & 25358 & 25673 & 32030 & 30054 & 29884 \\
\hline
\end{tabular}

Moreover, it is valid, at first sight, that the development of Russian economy which was followed by essential decrease in a share of the industry with a simultaneous growth of the services sector branches, corresponds to the theory of post-industrial society of Daniel Bell which has become popular in scientific community. Besides similar tendencies of postindustrial development were shown also in some developed countries. First, it is about decrease in a share of "old" industrial branches (such as metallurgy, nftural resource extraction) and growth of a share of the tertiary sector in structure of GDP of economically developed countries. Most brightly changes in structure of GDP are traced in the USA and Great Britain, so a service sector share in these economies of $79.7 \%$ and $78.5 \%$ respectively. On average in the world for 1960-2016 the industry share in GDP was reduced from 40 to $22.3 \%$, and a share of employed for $1960-2014$ - to $21 \%$ [2]. However, separately taken do not capture the essence of the occurring phenomena and should not be considered unambiguously as it only creates visibility of secondariness of the industrial sector in relation to the service sector and sciences, its backwardness in economy. In economically developed countries, the industry makes the basis, the strong base for other branches, and negative dynamics of an indicator of a share of the industry in GDP is explained not by compression of the industrial sector, but significant growth in the service sector.

Importance of the industrial sector in environmental and economic development of the state is confirmed by a statement, which was already repeatedly provided in scientific publications. One of the leading experts in the field of economy of development, professor of Harvard University Dani Rodrik said: "In the absence of a developed production sphere, 
societies seek a sharp stratification of the poor and of the gods and of environmental tension. After all, industry is the foundation of a viable democracy" [2].

H. Kagermann, the President of the German Academy of Technical Science has the same opinion, calling the industry by "ridge" of success for German economy [3].

Thus, attempts of realization of conceptual installations of post-industrial society (at not developed industrial sector) in Russia in total with carrying out the "neoliberal" policy were insolvent and have aggravated already difficult situation in economy and environment as well. Especially sharp problems were shown in the conditions of new economic reality when Russia has to accept internal and external calls. The most adequate answer to the existing challenges - a change of a strategic vector to the sustainable development of the country. The Russian economy needs deep structural transformations which will become the base of modernization and formation of a new strategy of economic growth capable to provide the sustainable development in the long-term period.

\section{Results and Discussion}

The result of this research is the understanding that at present for the Russian economy the implementation of the new industrialization policy is the only possible way to overcome technological backwardness and drift to sustainable development. In 2011, the need for structural changes was announced by the President, the course for a new industrialization, was chosen as a priority for the development of the Russian economy.

Theoretical developments in the field of the formation of an industrial model of sustainable development have been carried out for a long time. There was a point of view that Russia would never a post-industrial era, and the expansion of a raw-material sector is dragging the country into the distant past, which it's time to finish. However, as we can see today, the tone of the discussion has changed, and industrialization is seen as the only way to achieve quality economic growth combined with decreasing the environmental damage.

First, the very concept of "new industrialization" is considered from the point of view of a time and content approach. The temporary approach assumes that Russia has already undergone a process of accelerated build-up of industrial potential in the 1930s and at present a new or repeated implementation of the process of industrialization of the country's economy will take place. A meaningful approach is based on the concept of convergence, developed on the basis of the theory of a new industrial society. According to this concept in developed economies, the features of classical capitalism are blurring, by acquiring the traits of socialism, thus creating a new type-a third type of society, incorporating the features of both, which is called post-industrial. The formation of a post-industrial society is preceded by a stage called JK. Galbraith, a new industrialization, when from industry as the main sector of the economy, society passes to the dominant of the tertiary sector - the service sector.

Secondly, not created terms framework attracts attention. It leads to confusion of various concepts similar in contents, such as "new industrialization", "neoindustrialization", "superindustrialization", "the advancing industrial development", "reindustrialization".

Thirdly, the different sense invests also in the content of new industrialization. There are several points of view according to which, new industrialization is considered as:

- the forced development of the industrial sector promoting increase in quantity of jobs and reduction of unemployment to increase that increases the general level of competitiveness of the country.

- package of measures for import substitution and providing country with goods of own production [4]. 
- transition from the economy of raw, consumer type which is based on sale not of renewable resources to the economy which is characterized by the modern, technologically developed, innovative industrial base.

- creation in Russia of new technological way thanks to what we will be able not just to catch up with the West on production of the industrial goods existing for today but also to shoot ahead due to production of essentially new products.

Thus, scientific community just should "convert" the saved-up massif of knowledge into the harmonious, settled economic concept "new industrialization". In spite of the fact that among domestic scientists there is no consensus in questions of definition of tools and content of new industrialization, all of them are unanimous in understanding, the fact that the result of new industrialization has to be expressed by extensive economic growth with an exit to a trajectory of sustainable economic development.

However, implementation the "new industrialization" project in Russia of can "hang in mid-air" if specifics of technological layer will not be considered as defining the leading branches - "locomotives" of sustainable development of economy. The concept of technological layers recognizes that the level of development of production, which is based on certain technologies, forms specific industrial policy, the directions of scientific research and scales of use of their results in the industry is inherent in each of them. In process of productive forces development and scientific and technical progress, transition from low to higher technological layers is carried out. It corresponds to the conventional approach on the basis of Kondratieff's cycles, distinguishes six technological layers. Modern economic era is characterized by end of the fifth technological way of industrial production (1980 2030) and expansion of transition to the sixth technological way, which will create the bases of sustainable development in the future. [5]

About the sixth technological layer, we talk early. Russia is today mainly in the third, fourth and fifth stages of the fifth technological layer. Technologies of the fifth layer have received the greatest distribution in the national economy in the branches of the militaryindustrial complex and aerospace industry, traditionally considered the most developed, but their share is essentially small and does not exceed $10 \%$. Among the remaining industries, the largest number of technologies (more than 50\%) are at the fourth level, but no less significant share of technology (more than 30\%) and at all to the third. The backlog from developed countries is great, for example, in the United States, in the fifth technological order, about $60 \%$ of production operates. The greatest lag in the Russian economy is in information technology, which is the core of the fifth technological order [6].

Russia has missed the fifth technological layer, which was formed at the end of the 20th century. This fact allows understanding complexity of tasks of sustainable development and deployment of the new technologies facing domestic science and the industry. The prospect of inclusion of Russia into number of the states with the sixth technological way is real, however for this purpose it is necessary to make technological jump i.e. "to jump" through the fifth layer. Such transition to the sixth technological layer (without having mastered previous the fifth) and elimination of a gap with economies of the advanced countries of Russia require 50-60 years. For this period the majority of the developed countries will pass to the seventh or even to the eighth technological layer, significantly decreasing the environmental load. But not everything is so hopeless.

Process of change of technological layers in the developed countries happens not so quickly as in economy redistribution of the capital in productions of new technological way comes from productions of outdated technological way through structural crisis. For such countries, an exit from outdated way involves the heavy expenses connected with reconstruction of outdated productions, modernization of infrastructure, retraining of labor, etc. The lagging behind countries are not influenced by such difficulties of transition that creates for them a window of opportunities for technological breakthrough. Having directed 
the investments into environment-friendly productions in the branches of new technological layer, they can enter a long wave of economic growth quicker than other countries, that will allow them to shoot ahead and to leave in world leaders. According to such scenario, there were "economic miracles" of such countries as Japan, South Korea, Taiwan, Singapore and Hong Kong. So on the basis of new fourth technological layer, the economies of Japan and a number of countries of Western Europe, which have been thoroughly destroyed during World War II, have been restored. In the 1960th years, the new industrial countries having predicted before others key industries of new, fifth technological way. Japan has concentrated all forces on development of his key factor - microelectronics, having modernized also related branches. The taken actions have allowed the country to use the "window of opportunities" which has arisen at replacement of the fourth technological way with the fifth and to become the world leader in these areas, significantly improving environment situation.

Accordingly T.F. Bresnakhan and M. Traytenberg, who introduced in 1995 to a hypothesis of "an innovative pause", changing in the technological layers is due to operating "technologies of broad application" and new technologies, due to not sufficient massive application, are late and can't play this role yet [7]. Following the logic of the theory above, the possibility of increasing the productivity of labor of the 5th technological layer in the leading countries is exhausted, and a number of reasons (contractual obligations, contracts, waiting for investment return, the rapid diffusion of new technologies and the transition to a new technological base, etc). In this situation, countries where the inertial impact of previous technologies are less significant, gain advantages, which we call "windows of opportunity". Taking advantage of the "window of opportunity" gives the country a critical importance for the economy, as having missed them we can no longer catch up with the developed countries and will forever remain a commodity economy. However, it is not easy to realize the advantages that arise at the borders of technological structures, therefore, examples of countries that have managed to do so are few. By S.Yu. Glazyev's estimation, by 2020 the fifth layer would enter a fading phase, having exhausted reserves of the growth [8-9]. The structural crisis, which is characterized by the conflict between old structure of economy and inquiries of new technology, is the evidence of the beginning of reorganization of the economy connected with end of life cycle of the fifth layer and origin of the sixth technological layer. By estimates of different authors, today Russia has the potential allowing to pass to the fifth technological way and to fix some positions within the sixth layer of sustainable development. [10].

\section{Conclusion}

This study has defined the basic theoretical propositions use of advantages, which give to the country of "window of opportunities" on transition to sustainable development. For certain reasons, those stages of industrial development, which have passed the western countries, Russia haven't passed. The tasks set for our economy of course differ from problems of advanced economies, such as economy of Germany, the USA or other European countries, but to make economic breakthrough and to show "the Russian economic miracle" is quite possible.

To reach the level of sustainable development of the leading countries at a stage of origin of the layer it is necessary to use the potential of "window of opportunities", for what the concentration of efforts on carrying out policy of modernization is necessary.

Recession of public production, violation of normal functioning of the markets and the monetary sphere, emergence of "financial bubbles", fluctuation in prices of the main resources - all this signs of the approaching change of layers. The decline in industrial production, the disruption of the normal functioning of markets and the monetary sphere, 
the emergence of "financial bubbles", fluctuations in prices for basic resources - all these are signs of an impending change in the patterns. The current formation, further development and future development of the sixth technological layer will determine the sustainable development in the next 20-30 years. This period will be the intellectualization of production, the individualization of the product, the development of nano- and biotechnology, etc. Today Russia has the potential to move to the fifth technological order and consolidate some positions within the framework of the sixth order.

Thus, in modern conditions for Russia, the restoration of the role and place of industry as its base, the foundation of the economy, the basis of the achievements of the sixth technological layer becomes a priority of sustainable development. At the same time, the role of the state is to support demand in the domestic market (large-scale import substitution), assume risks and compensate for high costs of transition to new technologies. It is the innovative renewal of equipment and technologies of the basic branches of production, on the one hand, and the imparting of a high-tech and knowledge-intensive appearance to key areas of competence of the new technological order, on the other, and will mean a new industrialization applied to the Russian economy. This approach allows us to interpret the new industrialization as the process of creating new high technological sectors of the economy, while simultaneously effectively innovating the traditional sectors.

\section{References}

I. Silin, E. Animitsa, N. Novikova, Journal of Ural state University of Economics, 3:2, 14-25 (2016)

1. G. Korovin, Bulletin of Baikal state University, 3:65, 14-25 (2013)

2. E. Andreyeva, Perm congress of scientists-economists, 1, 11-15 (2015)

A. Maltsev, K. Mercier-Suissa, A. Mordvinova, Journal of Regional economy, 13:4, 1044-1054 (2017)

3. V. Prudsky, A. Oshchepkov, Perm congress of scientists-economists, 1, 82-86 (2015)

4. M. Parshin, D. Kruglov, Journal of Modern scientific research and innovation, 5:37, 17 (2014)

A. Urasova, J. of Ars Adm., 9:1, 52-61 (2017)

5. S. Glazyev, Journal of Economic issue, 3, 26-38 (2009)

6. S. Glazyev, The strategy of outstripping development of Russia in conditions of global crisis (Economy, Moscow, 2010)

7. E. Kolbachev, Bulletin of Russian University, 3, 6-15 (2015) 